\title{
Variation in protein and amino acids content among landraces of common bean (Phaseolus vulgaris L.)
}

\author{
Ángel Ramón Flores-Sosa ${ }^{1}$, Elia Nora Aquino-Bolaños ${ }^{1 *}$, Anaberta Cardador-Martínez², \\ José Luis Chávez-Servia ${ }^{3}$, Araceli Minerva Vera-Guzmán ${ }^{3}$, José Cruz Carrillo-Rodríguez ${ }^{4}$, \\ Jimena Esther Alba Jiménez ${ }^{5}$
}

${ }^{1}$ Universidad Veracruzana, Centro de Investigación y Desarrollo en Alimentos, Industrial Ánimas, 91190 Xalapa, Veracruz, México, ${ }^{2}$ Instituto
Tecnológico de Monterrey, Escuela de Ingeniería y Ciencias, Centro de Bioingeniería, Epigmenio González 500, Fracc. San Pablo, 76130,
Querétaro, México, ${ }^{3}$ CIIDIR-Oaxaca, Instituto Politécnico Nacional-México. Hornos 1003, Santa Cruz Xoxocotlán, 71230, Oaxaca, México,
${ }^{4}$ Instituto Tecnológico del Valle de Oaxaca, Oaxaca, México. Exhacienda Nazareno Santa Cruz Xoxocotlán, 71230, Oaxaca, México,
${ }^{5}$ CONACyT-Universidad Veracruzana, Centro de Investigación y Desarrollo en Alimentos, Industrial Ánimas, 91190 Xalapa, Veracruz, México

A B S T R A C T

\begin{abstract}
Native bean populations (Phaseolus vulgaris L.) provide bioactive and nutrient compounds; however, their amino acid profiles are unknown. Therefore, the aim of this study is to evaluate the protein content and amino acid profile of 46 native bean populations cultivated by small farmers in Oaxaca, Mexico, and compare them with that of commercial beans. Through high-performance liquid chromatography (HPLC), 16 amino acids were identified and quantified in all samples. The region of origin influenced the concentrations of amino acids. The Santa Lucia Miahuatlan populations stood out for their high content of isoleucine, threonine, methionine, arginine, serine, alanine, tyrosine, and cysteine. Amino acid content showed high variability among the populations; accessions labeled as FSLM22, FSLM27, FSLM28, and FSLM32 were enriched in aliphatic, hydroxylated, aromatic, acidic, and basic amino acids, while the FSLM14, FSLM17, and FSLM18 populations had the highest concentrations of sulfur amino acids. The FSLM01, FSLM22, FSLM27, FSLM28, FSLM30, and FSLM32 populations frequently displayed the highest concentrations of essential amino acids. The findings show that samples of native populations are highly variable in amino acid content due to the genetic characteristics of cultivated beans, environmental and agroecological influences, and crop management by farmers. The beans populations stood out can be used for direct use or a basis for the initiation of a breeding program.
\end{abstract}

Keywords: Amino acids; HPLC; Landraces; Phaseolus

\section{INTRODUCTION}

In Africa, America, and Asia, malnutrition or low protein and carbohydrate (energy) intake represents a health problem that is due partially to lack of access to sufficient quantity and quality of food (Black et al., 2013). Beans represent an important source of protein. In Africa and Latin America, beans contribute up to 20.29 and $12.9 \mathrm{~g}$ of protein per day, respectively, to the human diet (FAOSTAT, 2013). In Mexico, this legume provides almost all the protein that individuals require because it is highly consumed in rural communities (Pérez et al., 2002).

Depending on the bean type, protein content ranges

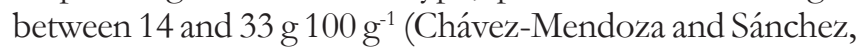
2017; Guzmán-Maldonado et al., 2000), recently Carbas et al. (2020) reported a similar interval in 10 common bean crops from Portugal (22.0-31.3 g 100-1), and Gundogan and Karaca (2020) recorded a narrower interval in four local

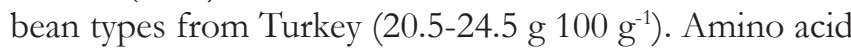
content in common beans has been recorded in a wide range, although most authors agree that the major essential amino acids are lysine (10-104 $\left.\mathrm{mg} \mathrm{g}^{-1}\right)$, leucine (14-92 $\mathrm{mg} \mathrm{g}^{-1}$ ) and phenylalanine + tyrosine (53-105 $\left.\mathrm{mg} \mathrm{g}^{-1}\right)$; conversely, bean lacks the sulfur amino acids: methionine + cysteine (4.0-20 $\mathrm{mg} \mathrm{g}^{-1}$ ) (Guzmán-Maldonado et al., 2000; ChávezMendoza and Sánchez, 2017; Baptista et al., 2017; Rezende, et al., 2018; Carbas et al., 2020).

The protein quality of a food is defined according to the variety and quantity of amino acids and its bioavailability. Consequently, protein absorption depends on the balance

\footnotetext{
${ }^{*}$ Corresponding author:

Elia Nora Aquino-Bolaños, Universidad Veracruzana, Centro de Investigación y Desarrollo en Alimentos, Industrial Ánimas, 91190 Xalapa, Veracruz, México. E-mail: eliaquino@uv.mx
} 
of amino acids (Gropper and Smith, 2013). The proportion of methionine, histidine, leucine, and tyrosine present in foods is associated with protein bioavailability (Alsmeyer et al., 1974).

Amino acids form part of the structural compounds of tissues, organs, muscles, and hormones and contribute to biological metabolism. Amino acids are involved in the regulation of metabolic processes that are vital for the growth, development, and homeostasis of the body (Boye et al., 2012). Some studies show that dietary supplementation with arginine, glutamine, leucine, and cysteine has a positive impact on health (Grimble, 2006, Marliss et al., 2006, Li et al., 2007, Freudenberg et al., 2012). Dietary supplementation with glutamine reduces glucocorticoid stress hormone production (Li et al., 2007), supplementation with cysteine reduces pathogenic antibody levels (Grimble, 2006), arginine helps reduce blood glucose (Marliss et al., 2006), and leucine reduces body weight and triglyceride levels (Freudenberg et al., 2012).

Amino acid concentrations in beans vary according to genetic and environmental factors, genotype-environment interaction, crop management, germplasm origin, and post-harvest grain processing (Kigel, 1999, GuzmánMaldonado et al., 2000, Audu and Aremu, 2011). In wild bean populations, Guzmán-Maldonado et al. (2000) found differences in germplasm between and within regions of origin in sulfur, aromatic, and leucine amino acid content. Regarding crop management, Kigel (1999) reported that nitrogen and sulfur increased protein content and sulfur amino acid level in grains. In turn, Audu and Aremu (2011) noted that cooking methods (boiling, cooking, and roasting) had no impact on lysine, threonine, or sulfur amino acid content. However, isoleucine, leucine, and valine content decreased with roasting, while boiling decreased the concentrations of isoleucine and of aromatic amino acids in commercial varieties (Sotelo et al., 1995). Few or no records on landraces are available.

Mexico, Central and South America are the center of origin, domestication, and diversification of the common bean, and there is in situ conservation of a high diversity of landraces and wild forms in farms and backyards (Bitochi et al., 2012). These ecotypes, populations, and landraces differ not only with respect to the phenotypic and genetic characteristics of the plants and grains (Worthington et al., 2012; Soleri et al., 2013) but also in their content of bioactive compounds and minerals (Chávez-Servia et al., 2016).

Native bean populations have been characterized according to their mineral and bioactive compound content and their antioxidant activity (Chávez-Servia et al., 2016). However, the composition and variation of amino acid content in grain is unknown. In this sense, any contribution will enhance grain consumption and improve health. Consistent with this, the objective of this study was to evaluate the protein content and amino acid profile of 46 bean landraces from two municipalities of Oaxaca, México, and compare them with that of commercial beans.

\section{MATERIAL AND METHODS}

\section{Samples of germplasm evaluated}

From December 2016 to March 2017, samples of 46 native bean populations (Phaseolus vulgaris L. and Phaseolus

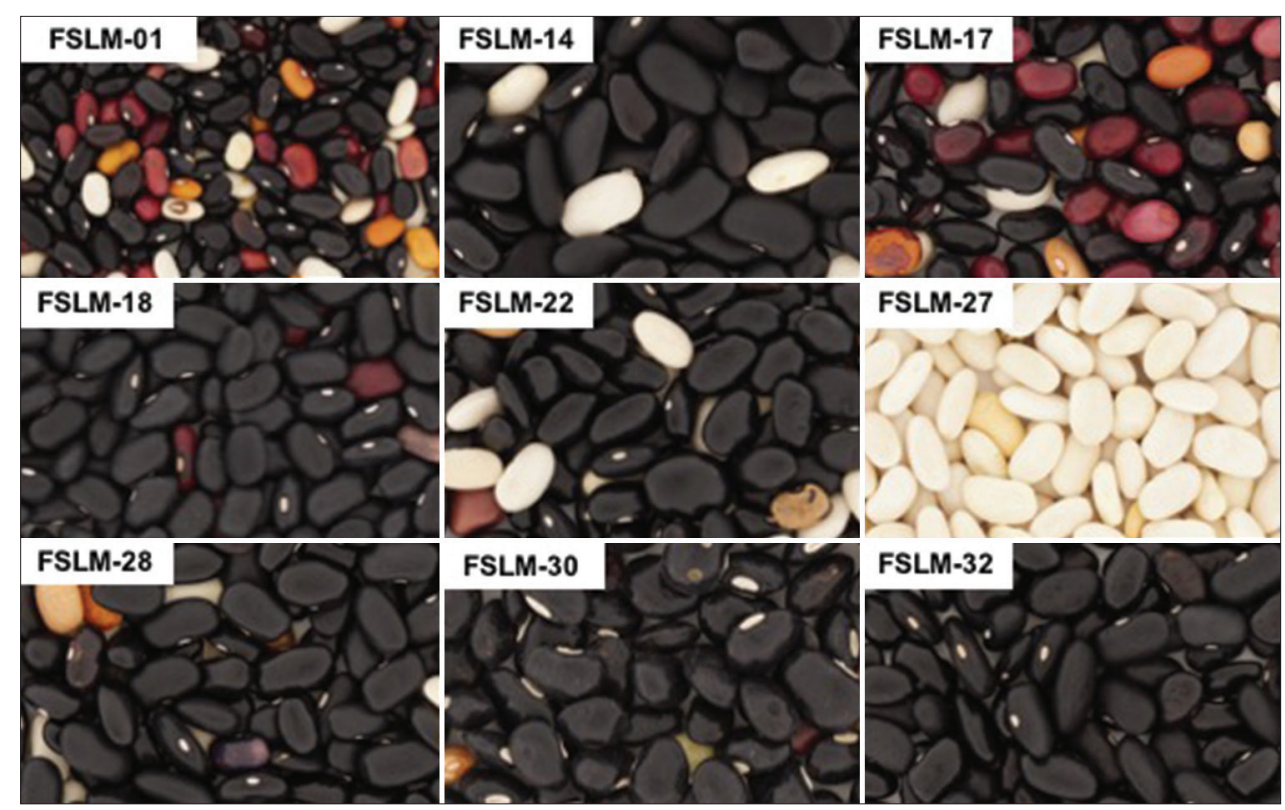

Fig 1. Grain of some bean accessions (Phaseolus vulgaris L.) evaluated 
Table 1: List of evaluated populations of native common beans collected at Santa Lucia Miahuatlan (SLM) and Coatecas Altas (CA), Oaxaca, Mexico

\begin{tabular}{|c|c|c|c|c|}
\hline Populations ID & Location and municipalities & Latitude (N) & Longitude (O) & Altitude (masl) \\
\hline FSLM01 & Santa Lucia Miahuatlan & $16^{\circ} 12^{\prime} 20.1^{\prime \prime}$ & $96^{\circ} 37^{\prime} 32.3^{\prime \prime}$ & 1911 \\
\hline FSLM02* & Santa Lucia Miahuatlan & $16^{\circ} 12^{\prime} 20.1^{\prime \prime}$ & $96^{\circ} 37^{\prime} 32.3^{\prime \prime}$ & 1911 \\
\hline FSLM03* & Santa Lucia Miahuatlan & $16^{\circ} 12^{\prime} 20.1^{\prime \prime}$ & $96^{\circ} 37^{\prime} 32.3^{\prime \prime}$ & 1911 \\
\hline FSLM04 & Santa Lucia Miahuatlan & $16^{\circ} 12^{\prime} 20.1^{\prime \prime}$ & $96^{\circ} 37^{\prime} 32.3^{\prime \prime}$ & 1911 \\
\hline FSLM05 & Santa Lucia Miahuatlan & $16^{\circ} 12^{\prime} 20.1^{\prime \prime}$ & $96^{\circ} 37^{\prime} 32.3^{\prime \prime}$ & 1911 \\
\hline FSLM06 & Santa Lucia Miahuatlan & $16^{\circ} 12^{\prime} 20.1^{\prime \prime}$ & $96^{\circ} 37^{\prime} 32.3^{\prime \prime}$ & 1911 \\
\hline FSLM07 & Santa Lucia Miahuatlan & $16^{\circ} 12^{\prime} 20.1^{\prime \prime}$ & $96^{\circ} 37^{\prime} 32.3^{\prime \prime}$ & 1911 \\
\hline FSLM08 & Santa Lucia Miahuatlan & $16^{\circ} 12^{\prime} 20.1^{\prime \prime}$ & $96^{\circ} 37^{\prime} 32.3^{\prime \prime}$ & 1911 \\
\hline FSLM09 & Santa Lucia Miahuatlan & $16^{\circ} 12^{\prime} 20.1^{\prime \prime}$ & $96^{\circ} 37^{\prime} 32.3^{\prime \prime}$ & 1911 \\
\hline FSLM10* & Santa Lucia Miahuatlan & $16^{\circ} 12^{\prime} 20.1^{\prime \prime}$ & $96^{\circ} 37^{\prime} 32.3^{\prime \prime}$ & 1911 \\
\hline FSLM11* & Llano Grande, Sta. L. Miahuatlan & $16^{\circ} 11^{\prime} 40.7^{\prime \prime}$ & $96^{\circ} 37^{\prime} 52.9^{\prime \prime}$ & 2301 \\
\hline FSLM12 & Santa Lucia Miahuatlan & $16^{\circ} 12^{\prime} 20.1^{\prime \prime}$ & $96^{\circ} 37^{\prime} 32.3^{\prime \prime}$ & 1911 \\
\hline FSLM13 & Santa Lucia Miahuatlan & $16^{\circ} 12^{\prime} 20.1^{\prime \prime}$ & $96^{\circ} 37^{\prime} 32.3^{\prime \prime}$ & 1911 \\
\hline FSLM14 & Santa Lucia Miahuatlan & $16^{\circ} 12^{\prime} 20.1^{\prime \prime}$ & $96^{\circ} 37^{\prime} 32.3^{\prime \prime}$ & 1911 \\
\hline FSLM15 & Santa Lucia Miahuatlan & $16^{\circ} 12^{\prime} 20.1^{\prime \prime}$ & $96^{\circ} 37^{\prime} 32.3^{\prime \prime}$ & 1912 \\
\hline FSLM16 & La Cofradía, Sta. L. Miahuatlan & $16^{\circ} 07^{\prime} 25.7^{\prime \prime}$ & $96^{\circ} 37^{\prime} 06.5^{\prime \prime}$ & 853 \\
\hline FSLM17 & La Cofradía, Sta. L. Miahuatlan & $16^{\circ} 07^{\prime} 25.7^{\prime \prime}$ & $96^{\circ} 37^{\prime} 06.5^{\prime \prime}$ & 853 \\
\hline FSLM18 & La Cofradía, Sta. L. Miahuatlan & $16^{\circ} 07^{\prime} 25.7^{\prime \prime}$ & $96^{\circ} 37^{\prime} 06.5^{\prime \prime}$ & 853 \\
\hline FSLM19 & La Chinilla, Sta. L. Miahuatlan & $16^{\circ} 01^{\prime} 26.5^{\prime \prime}$ & $96^{\circ} 36^{\prime} 10.2^{\prime \prime}$ & 1215 \\
\hline FSLM20 & Santa Lucia Miahuatlan & $16^{\circ} 12^{\prime} 20.1^{\prime \prime}$ & $96^{\circ} 37^{\prime} 32.3^{\prime \prime}$ & 1912 \\
\hline FSLM21 & Santa Lucia Miahuatlan & $16^{\circ} 12^{\prime} 20.1^{\prime \prime}$ & $96^{\circ} 37^{\prime} 32.3^{\prime \prime}$ & 1912 \\
\hline FSLM22 & Santa Lucia Miahuatlan & $16^{\circ} 12^{\prime} 20.1^{\prime \prime}$ & $96^{\circ} 37^{\prime} 32.3^{\prime \prime}$ & 1912 \\
\hline FSLM23 & San Isidro el Queyón, Sta. L. Miahuatlan & $16^{\circ} 13^{\prime} 35.2^{\prime \prime}$ & $96^{\circ} 38^{\prime} 53.2^{\prime \prime}$ & 2159 \\
\hline FSLM24 & San Isidro el Queyón, Sta. L. Miahuatlan & $16^{\circ} 13^{\prime} 35.2^{\prime \prime}$ & $96^{\circ} 38^{\prime} 53.2^{\prime \prime}$ & 2159 \\
\hline FSLM26 & San Isidro el Queyón, Sta. L. Miahuatlan & $16^{\circ} 13^{\prime} 35.2^{\prime \prime}$ & $96^{\circ} 38^{\prime} 53.2^{\prime \prime}$ & 2159 \\
\hline FSLM27 & Rio Comal, Sta. L. Miahuatlan & $16^{\circ} 13^{\prime} 53.5^{\prime \prime}$ & $96^{\circ} 38^{\prime} 5.66^{\prime \prime}$ & 1874 \\
\hline FSLM28 & Rio Comal, Sta. L. Miahuatlan & $16^{\circ} 13^{\prime} 53.5^{\prime \prime}$ & $96^{\circ} 38^{\prime} 5.66^{\prime \prime}$ & 1874 \\
\hline FSLM29 & Rio Comal, Sta. L. Miahuatlan & $16^{\circ} 13^{\prime} 53.5^{\prime \prime}$ & $96^{\circ} 38^{\prime} 5.66^{\prime \prime}$ & 1874 \\
\hline FSLM30* & Santa Lucia Miahuatlan & $16^{\circ} 12^{\prime} 20.1^{\prime \prime}$ & $96^{\circ} 37^{\prime} 32.3^{\prime \prime}$ & 1912 \\
\hline FSLM31 & El Sumidero, Sta. L. Miahuatlan & $16^{\circ} 12^{\prime} 12.26^{\prime \prime}$ & $96^{\circ} 36^{\prime} 33.34^{\prime \prime}$ & 2051 \\
\hline FSLM32 & El Sumidero, Sta. L. Miahuatlan & $16^{\circ} 12^{\prime} 12.26^{\prime \prime}$ & $96^{\circ} 36^{\prime} 33.34^{\prime \prime}$ & 2051 \\
\hline FCA01 & Coatecas Altas & $16^{\circ} 32 ' 12.3^{\prime \prime}$ & $96^{\circ} 39^{\prime} 53.9^{\prime \prime}$ & 1546 \\
\hline FCA02 & Coatecas Altas & $16^{\circ} 32 ' 12.3^{\prime \prime}$ & $96^{\circ} 39^{\prime} 53.9^{\prime \prime}$ & 1546 \\
\hline FCA03 & Coatecas Altas & $16^{\circ} 32^{\prime} 12.3^{\prime \prime}$ & $96^{\circ} 39^{\prime} 53.9^{\prime \prime}$ & 1546 \\
\hline $\mathrm{FCAO4}^{*}$ & Coatecas Altas & $16^{\circ} 32^{\prime} 12.3^{\prime \prime}$ & $96^{\circ} 39^{\prime} 53.9^{\prime \prime}$ & 1546 \\
\hline FCA05 & Coatecas Altas & $16^{\circ} 32^{\prime} 12.3^{\prime \prime}$ & $96^{\circ} 39^{\prime} 53.9^{\prime \prime}$ & 1546 \\
\hline FCA06* $^{*}$ & Coatecas Altas & $16^{\circ} 32^{\prime} 12.3^{\prime \prime}$ & $96^{\circ} 39^{\prime} 53.9^{\prime \prime}$ & 1546 \\
\hline $\mathrm{FCAO7}^{*}$ & Coatecas Altas & $16^{\circ} 32^{\prime} 12.3^{\prime \prime}$ & $96^{\circ} 39^{\prime} 53.9^{\prime \prime}$ & 1546 \\
\hline FCA08 & Coatecas Altas & $16^{\circ} 32 ' 12.3^{\prime \prime}$ & $96^{\circ} 39^{\prime} 53.9^{\prime \prime}$ & 1546 \\
\hline FCA09 & Coatecas Altas & $16^{\circ} 32^{\prime} 12.3^{\prime \prime}$ & $96^{\circ} 39^{\prime} 53.9^{\prime \prime}$ & 1546 \\
\hline FCA10 & Coatecas Altas & $16^{\circ} 32^{\prime} 12.3^{\prime \prime}$ & $96^{\circ} 39^{\prime} 53.9^{\prime \prime}$ & 1546 \\
\hline FCA12 & Coatecas Altas & $16^{\circ} 32^{\prime} 12.3^{\prime \prime}$ & $96^{\circ} 39^{\prime} 53.9^{\prime \prime}$ & 1546 \\
\hline FCA13 & Coatecas Altas & $16^{\circ} 32^{\prime} 12.3^{\prime \prime}$ & $96^{\circ} 39^{\prime} 53.9^{\prime \prime}$ & 1546 \\
\hline FCA14* & San Antonio Poblete, Coatecas Altas & $16^{\circ} 31^{\prime} 15.1^{\prime \prime}$ & $96^{\circ} 35^{\prime} 46.9^{\prime \prime}$ & 1497 \\
\hline FCA15 & Las Salinas, Coatecas Altas & $16^{\circ} 28^{\prime} 39.0^{\prime \prime}$ & $96^{\circ} 34^{\prime} 04.6^{\prime \prime}$ & 1459 \\
\hline FCA16 & Las Salinas, Coatecas Altas & $16^{\circ} 28^{\prime} 39.0^{\prime \prime}$ & $96^{\circ} 34^{\prime} 04.6^{\prime \prime}$ & 1459 \\
\hline
\end{tabular}

*Phaseolus coccineus. masl: meters above sea level

coccineus $\mathrm{L}$.) were collected from farmers in the municipalities of Coatecas Altas (15) and Santa Lucia Miahuatlan (31), Oaxaca, Mexico (Table 1, Figure 1). Three commercial varieties were included as controls: Michigan (black), Black Horse (black) and Peruvian. All grain samples were stored at $-4{ }^{\circ} \mathrm{C}$ until analysis.

\section{Protein content analysis}

A homogeneous flour sample was obtained from each bean sample to measure the protein content according to the method described by Bradford (1976). The quantification was based on a standard curve obtained using samples of bovine albumin (Sigma-Aldrich, Saint Louis, MO, USA) 
at concentrations ranging from 0.0005 to $0.018 \mathrm{mg} \mathrm{mL}^{-1}$ $\left(r^{2}=0.9968\right)$.

\section{Amino acid content analysis}

Amino acid hydrolysis was conducted according to the method described by Alaiz et al. (1992) with the following modifications: $10 \mathrm{~mL}$ of $6 \mathrm{~N} \mathrm{HCl}$ and $200 \mu \mathrm{L}$ of $\beta$-mercaptoethanol were added to $1 \mathrm{~g}$ of flour. The mixture was incubated for $24 \mathrm{~h}$ at $110^{\circ} \mathrm{C}$ under a nitrogen atmosphere. The determination of amino acids was conducted through high-performance liquid chromatography (HPLC Agilent Series 1260, Palo Alto, CA, USA), according to the method proposed by Henderson et al. (2000). Amino acids standard ( $0.005 \mathrm{mg} \mathrm{mL}^{-1}$ to $0.5 \mathrm{mg} \mathrm{mL}^{-1}$ ) calibration curves were used to identify and quantitate the amino acids. The coefficient of determination $\left(\mathrm{r}^{2}\right)$ for the standard curves ranged from 0.9983 to 0.9999 .

\section{Statistical analysis}

Two databases, one for protein content and another for amino acids, with their respective repetitions were set up for each population. To compare the differences between municipalities of origin and among populations, analysis of variance was conducted using a completely random model. In this case, we considered a nesting population effect within municipalities of origin. Multiple comparisons were performed using the Tukey method $(\mathrm{P} \leq 0.05)$.

\section{RESULTS}

Based on retention time, 16 amino acids were identified by HPLC analysis; they eluted in the following order: aspartic acid, glutamic acid, serine, histidine, glycine, threonine, arginine, alanine, tyrosine, cysteine, valine, methionine, isoleucine, phenylalanine, leucine, and lysine (Figure 2).

The analysis of variance showed significant differences $(\mathrm{P} \leq 0.05)$ in protein and amino acid content between populations with different municipalities of origin and among the evaluated populations. The greater variance due to municipalities of origin highlights the marked influence of the agroecological conditions in the cultivation region. In protein content was estimated a low coefficient of variation $(4.1 \%)$ and in amino acids presented a ranged from 13.2 to $24.6 \%$ (Table 2).

Comparison of the means for the municipalities of origin and the control group showed that the latter had the highest protein content, followed by Coatecas Altas and Santa Lucia Miahuatlan (Table 3). Populations from Santa Lucia Miahuatlan displayed higher content of all evaluated amino acids, except histidine, than those from Coatecas Altas. A similar content of lysine, leucine, glutamic acid, aspartic acid, and glycine was found in the control group and in populations from Santa Lucia Miahuatlan. The populations from Santa Lucia Miahuatlan surpassed the controls in isoleucine, threonine, methionine, arginine, serine, alanine, tyrosine, and cysteine content. The control group (Black Horse, Michigan, and Peruvian) surpassed the mean of the populations of both municipalities of origin in its content of valine, phenylalanine, and histidine.

Protein content differs significantly $(\mathrm{P} \leq 0.05)$ among bean populations. The controls (Michigan, Peruvian, and Black Horse) showed the highest protein content $(20 \%$ to $21.3 \%$ ). No significant differences were found between the controls and a group of populations from Coatecas Altas and Santa Lucia Miahuatlan (FCA12, FCA05, FCA03, FCA01, FSLM03, FSLM05, FSLM06, FSLM08, and FSLM09); these populations had values between 18.4\% and $19.9 \%$ (Table 4). This indicates that landraces in Santa Lucia Miahuatlan and Coatecas Altas have protein content similar to that in commercial varieties.

The aliphatic amino acid content differed significantly among populations. The Michigan and Peruvian controls only showed high glycine, leucine, and isoleucine content,

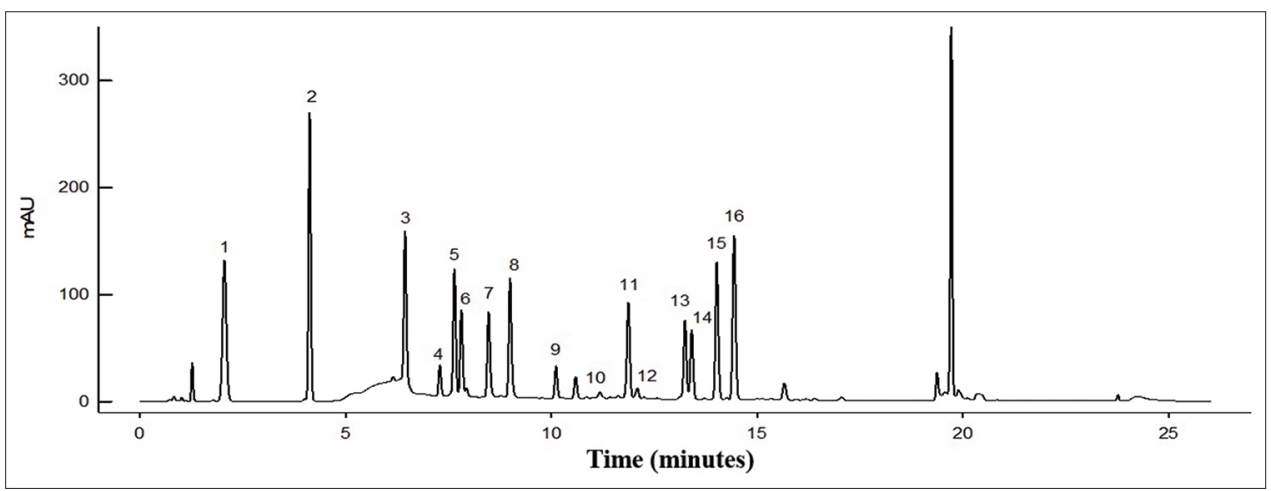

Fig 2. Chromatogram obtained by HPLC with UV detection at $338 \mathrm{~nm}$ showing the elution profile of 16 amino acids: aspartate (1), glutamic acid (2), serine (3), histidine (4), glycine (5), threonine (6), arginine (7), alanine (8), tyrosine (9), cysteine (10), valine (11), methionine (12), phenylalanine (13), isoleucine (14), leucine (15), and lysine (16) 
Table 2: Significance of square means determined in the analysis of variance in the protein and amino acid content of native bean populations

\begin{tabular}{|c|c|c|c|c|}
\hline \multirow[t]{2}{*}{ Protein/ amino acids } & \multicolumn{3}{|c|}{ Sources of variation } & \multirow[t]{2}{*}{ Coeficient of variation (\%) } \\
\hline & Municipality (M) & Populations/M1 & Error & \\
\hline Protein & $88.4^{\star \star}$ & $9.8^{* *}$ & 0.5 & 4.1 \\
\hline Lysine & $142151.9^{* *}$ & $7780.9^{* *}$ & 138.7 & 13.3 \\
\hline Leucine & $29034.9^{\star \star}$ & $4478.7^{\star *}$ & 164.5 & 13.8 \\
\hline Isoleucine & $15937.6^{\star \star}$ & $1320.8^{* *}$ & 38.7 & 17.8 \\
\hline Threonine & $7532.1^{\star \star}$ & $1783.1^{* *}$ & 21.4 & 14.3 \\
\hline Valine & $10417.8^{* *}$ & $1349.0^{* *}$ & 40.3 & 16.2 \\
\hline Phenylalanine & $5591.6^{\star *}$ & $1406.4^{* *}$ & 39.2 & 14.8 \\
\hline Histidine & $143.3^{* *}$ & $581.7^{\star \star}$ & 12.6 & 19.1 \\
\hline Methionine & $383.4^{* *}$ & $63.4^{\star \star}$ & 2.9 & 23.8 \\
\hline Glutamic acid & $161152.4^{* *}$ & $11780.9^{\star \star}$ & 465.2 & 17.0 \\
\hline Aspartic acid & $129303.2^{* *}$ & $8431.1^{* *}$ & 263.9 & 16.4 \\
\hline Arginine & $6072.8^{\star \star}$ & $1903.7^{\star *}$ & 80.3 & 13.7 \\
\hline Serine & $143170.2^{\star *}$ & $6720.7^{\star \star}$ & 120.5 & 13.2 \\
\hline Glycine & $1424.0^{* \star}$ & $294.8^{* *}$ & 12.4 & 14.0 \\
\hline Alanine & $6129.3^{* *}$ & $626.8^{\star *}$ & 24.6 & 13.5 \\
\hline Tyrosine & $1620.4^{* *}$ & $273.7^{* *}$ & 12.9 & 14.3 \\
\hline Cysteine & $121.2^{\star *}$ & $14.6^{\star *}$ & 1.3 & 24.6 \\
\hline
\end{tabular}

${ }^{1}$ Nesting of populations in municipalities of origin

Table 3: Protein and amino acid content of populations of native common beans grouped according to two municipalities of origin versus a group of improved varieties (controls)

\begin{tabular}{lccc}
\hline Protein/ amino acid ${ }^{1}$ & Sta. L. Miahuatlan $\left(\mathbf{3 1 ^ { 3 }}\right)$ & Coatecas Altas (15) & Controls (3) \\
\hline Protein $\left(\mathrm{g} 100 \mathrm{~g}^{-1} \mathrm{dw}\right)$ & $16.4^{\mathrm{c}}$ & $17.6^{\mathrm{b}}$ & $20.8^{\mathrm{a}}$ \\
Lysine $^{2}$ & $109.0^{\mathrm{a}}$ & $41.7^{\mathrm{b}}$ & $110.4^{\mathrm{a}}$ \\
Leucine $^{2}$ & $102.3^{\mathrm{a}}$ & $71.6^{\mathrm{b}}$ & $100.1^{\mathrm{a}}$ \\
Isoleucine $^{2}$ & $42.3^{\mathrm{a}}$ & $19.4^{\mathrm{c}}$ & $36.6^{\mathrm{b}}$ \\
Threonine $^{2}$ & $37.5^{\mathrm{a}}$ & $21.8^{\mathrm{c}}$ & $33.5^{\mathrm{b}}$ \\
Valine $^{2}$ & $44.4^{\mathrm{b}}$ & $26.5^{\mathrm{c}}$ & $47.9^{\mathrm{a}}$ \\
Phenylalanine $^{2}$ & $45.0^{\mathrm{b}}$ & $33.8^{\mathrm{c}}$ & $55.8^{\mathrm{a}}$ \\
Hystidine $^{2}$ & $18.2^{\mathrm{b}}$ & $18.5^{\mathrm{b}}$ & $22.4^{\mathrm{a}}$ \\
Methionine $^{2}$ & $8.3^{\mathrm{a}}$ & $4.8^{\mathrm{c}}$ & $6.0^{\mathrm{b}}$ \\
Glutamic acid $_{\text {Aspartic acid }}$ & $149.5^{\mathrm{a}}$ & $77.3^{\mathrm{b}}$ & $144.6^{\mathrm{a}}$ \\
Arginine & $119.3^{\mathrm{a}}$ & $54.5^{\mathrm{b}}$ & $112.5^{\mathrm{a}}$ \\
Serine & $70.1^{\mathrm{a}}$ & $56.0^{\mathrm{c}}$ & $64.4^{\mathrm{b}}$ \\
Glycine & $106.7^{\mathrm{a}}$ & $40.2^{\mathrm{c}}$ & $52.9^{\mathrm{b}}$ \\
Alanine & $27.8^{\mathrm{a}}$ & $21.1^{\mathrm{b}}$ & $28.3^{\mathrm{a}}$ \\
Tyrosine & $44.9^{\mathrm{a}}$ & $30.7^{\mathrm{c}}$ & $37.8^{\mathrm{b}}$ \\
Cysteine & $27.6^{\mathrm{a}}$ & $20.6^{\mathrm{b}}$ & $21.3^{\mathrm{b}}$ \\
\hline
\end{tabular}

${ }^{1}$ Content of amino acids in $\mathrm{mg}$ g-1 protein, 2 content of essential amino acids; 3 number of populations per group of origin

in contrast to the Santa Lucia Miahuatlan populations FSLM01, FSLM17, FSLM22, FSLM27, FSLM28, FSLM29, FSLM30, and FSLM32, which showed high levels of all aliphatic amino acids (glycine, alanine, valine, leucine, and isoleucine). In general, the aliphatic amino acid content of the Coatecas Altas populations was low, with the exception of populations FCA03, FCA07, and FCA14 (Table 4). The composition of the hydroxylated amino acids serine and threonine were inversely related. That is, if the serine content was high, the threonine concentration tended to be low (FSLM06, FSLM07, FSLM08, and FSLM13). Other cases (FSLM01, FSLM18, FSLM19, FSLM20, FSLM21, FSLM22,
FSLM23, and FSLM24) showed lower serine concentrations and higher threonine concentrations. In contrast, FSLM27, FSLM28, FSLM29, FSLM30, FSLM31, and FSLM32 showed high serine and threonine values. A group of Coatecas Altas populations (FCA02, FCA03, FCA06, FCA07, FCA10, FCA12, FCA13, FCA15, and FCA16) had low values for both compounds (Table 4). Thus, all possible patterns that might be required for feeding are available, although it seems intuitive to want high levels of both amino acids.

We found high variation in the concentrations of the aromatic amino acids phenylalanine and tyrosine in grain. 
Table 4: Content of protein and of aliphatic and hydroxyl amino acids in common bean populations cultivated in Coatecas Altas (CA) and Santa Lucia Miahuatlan (SLM), Oaxaca, Mexico

\begin{tabular}{|c|c|c|c|c|c|c|c|c|}
\hline \multirow[t]{2}{*}{ Population ID } & \multirow[t]{2}{*}{ Protein (\%) } & \multicolumn{5}{|c|}{ Aliphatic ( $\mathrm{mg} \mathrm{g}^{-1}$ de proteína) } & \multicolumn{2}{|c|}{ hydroxylate ( $\mathrm{mg} \mathrm{g}^{-1}$ de proteína) } \\
\hline & & Gly & Ala & $\mathrm{Val}^{2}$ & Leu $^{2}$ & $1 \mathrm{Ie}^{2}$ & Ser & Thr $^{2}$ \\
\hline FSLM01 & 15.1 & 31.3 & 51.6 & 56.9 & 123.3 & 51.8 & 80.0 & 35.1 \\
\hline FSLM02 & 15.8 & 17.5 & 46.4 & 23.4 & 56.8 & 16.4 & 82.0 & 16.5 \\
\hline FSLM03 & 19.5 & 15.7 & 32.8 & 14.9 & 54.2 & 11.5 & 57.3 & 11.8 \\
\hline FSLM04 & 17.9 & 25.8 & 31.7 & 30.2 & 88.6 & 27.7 & 80.8 & 22.5 \\
\hline FSLM05 & 18.4 & 29.5 & 38.0 & 49.8 & 108.5 & 45.4 & 59.1 & 31.7 \\
\hline FSLM06 & 19.8 & 29.1 & 38.7 & 44.3 & 105.3 & 40.5 & 126.9 & 15.4 \\
\hline FSLM07 & 16.8 & 18.7 & 32.9 & 25.2 & 66.4 & 21.4 & 112.0 & 12.3 \\
\hline FSLM08 & 19.3 & 18.5 & 24.0 & 24.8 & 67.3 & 23.1 & 97.7 & 14.1 \\
\hline FSLM09 & 19.6 & 22.6 & 25.5 & 20.4 & 58.2 & 19.0 & 78.3 & 10.0 \\
\hline FSLM10 & 16.5 & 22.3 & 37.6 & 28.3 & 81.5 & 26.1 & 77.7 & 17.7 \\
\hline FSLM11 & 14.7 & 29.2 & 45.6 & 46.5 & 100.7 & 42.2 & 81.2 & 29.4 \\
\hline FSLM12 & 15.7 & 28.2 & 44.7 & 36.0 & 101.4 & 43.2 & 126.5 & 21.5 \\
\hline FSLM13 & 16.9 & 17.4 & 36.3 & 21.1 & 56.8 & 21.4 & 93.5 & 16.8 \\
\hline FSLM14 & 17.5 & 23.0 & 44.2 & 34.0 & 85.7 & 39.1 & 82.4 & 16.2 \\
\hline FSLM15 & 17.1 & 27.5 & 41.5 & 44.7 & 103.2 & 44.0 & 111.3 & 45.6 \\
\hline FSLM16 & 17.4 & 29.1 & 45.4 & 41.2 & 107.3 & 52.1 & 120.6 & 51.5 \\
\hline FSLM17 & 14.0 & 32.9 & 54.8 & 56.7 & 129.5 & 62.1 & 142.3 & 66.9 \\
\hline FSLM18 & 17.5 & 20.4 & 35.6 & 37.7 & 82.6 & 42.3 & 75.2 & 39.8 \\
\hline FSLM19 & 17.1 & 29.5 & 50.7 & 65.2 & 111.5 & 64.7 & 88.2 & 60.0 \\
\hline FSLM20 & 15.7 & 26.2 & 50.4 & 65.2 & 110.0 & 58.7 & 88.8 & 50.5 \\
\hline FSLM21 & 16.6 & 26.2 & 44.8 & 47.5 & 103.0 & 52.7 & 75.1 & 52.8 \\
\hline FSLM22 & 12.2 & 38.0 & 60.6 & 61.2 & 142.4 & 75.6 & 93.7 & 85.8 \\
\hline FSLM23 & 14.7 & 29.8 & 49.2 & 46.2 & 114.5 & 49.6 & 70.8 & 68.8 \\
\hline FSLM24 & 17.5 & 19.4 & 45.8 & 49.1 & 90.6 & 42.0 & 76.7 & 43.1 \\
\hline FSLM26 & 17.8 & 17.6 & 42.1 & 19.8 & 63.3 & 15.4 & 85.5 & 16.4 \\
\hline FSLM27 & 17.9 & 38.3 & 53.0 & 65.2 & 142.5 & 54.5 & 207.4 & 48.9 \\
\hline FSLM28 & 15.3 & 36.8 & 55.4 & 63.6 & 140.5 & 54.0 & 188.2 & 47.2 \\
\hline FSLM29 & 16.9 & 37.2 & 57.8 & 69.7 & 144.6 & 59.6 & 134.0 & 47.9 \\
\hline FSLM30 & 12.6 & 43.8 & 63.3 & 75.2 & 150.5 & 60.7 & 174.6 & 59.9 \\
\hline FSLM31 & 13.5 & 37.2 & 51.6 & 48.7 & 128.3 & 39.8 & 156.7 & 44.5 \\
\hline FSLM32 & 12.0 & 42.8 & 59.6 & 62.8 & 152.6 & 55.4 & 184.2 & 62.0 \\
\hline FCA01 & 19.9 & 16.4 & 15.3 & 13.8 & 43.4 & 6.8 & 24.4 & 11.2 \\
\hline FCA02 & 17.4 & 16.4 & 22.6 & 18.9 & 55.3 & 10.1 & 35.9 & 17.6 \\
\hline FCA03 & 18.7 & 28.9 & 41.6 & 50.9 & 115.2 & 46.4 & 61.0 & 39.5 \\
\hline FCA04 & 17.3 & 21.0 & 33.4 & 22.5 & 63.2 & 15.1 & 30.3 & 27.6 \\
\hline FCA05 & 19.1 & 22.2 & 27.6 & 25.6 & 70.8 & 21.2 & 41.0 & 29.4 \\
\hline FCA06 & 17.8 & 22.9 & 19.8 & 16.7 & 50.8 & 10.5 & 31.4 & 16.7 \\
\hline FCA07 & 17.3 & 10.6 & 52.7 & 36.6 & 77.1 & 25.2 & 20.4 & 19.6 \\
\hline FCA08 & 17.5 & 28.0 & 38.0 & 32.4 & 99.0 & 26.7 & 74.6 & 29.7 \\
\hline FCA09 & 16.7 & 24.2 & 44.9 & 35.1 & 95.5 & 28.7 & 49.8 & 21.1 \\
\hline FCA10 & 16.4 & 21.0 & 24.3 & 24.5 & 66.0 & 17.4 & 39.0 & 19.0 \\
\hline FCA12 & 18.8 & 19.7 & 18.0 & 14.4 & 51.1 & 9.9 & 28.6 & 13.2 \\
\hline FCA13 & 17.7 & 19.6 & 22.6 & 19.3 & 60.8 & 13.7 & 37.5 & 18.4 \\
\hline FCA14 & 16.8 & 30.6 & 38.8 & 40.3 & 105.5 & 35.5 & 60.3 & 33.7 \\
\hline FCA15 & 16.4 & 16.8 & 39.1 & 19.7 & 54.5 & 14.7 & 28.4 & 13.3 \\
\hline FCA16 & 16.2 & 18.7 & 22.4 & 26.8 & 66.4 & 9.5 & 39.6 & 16.5 \\
\hline Black H. & 20.0 & 26.5 & 33.9 & 44.9 & 93.5 & 33.4 & 49.1 & 31.6 \\
\hline Michigan & 21.1 & 28.5 & 40.2 & 49.6 & 100.0 & 36.0 & 53.2 & 34.8 \\
\hline Peruvian & 21.3 & 30.0 & 39.3 & 49.2 & 106.8 & 40.3 & 56.4 & 34.0 \\
\hline DHS-Tukey ${ }^{1}$ & 2.4 & 14.3 & 12.3 & 14.8 & 29.9 & 14.5 & 25.6 & 10.8 \\
\hline
\end{tabular}

${ }^{1} \mathrm{DHS}=$ Honest significant difference as shown by Tukey's test; differences equal to or greater than Tukey's value indicates significant differences; ${ }^{2} \mathrm{Content}$ of essential amino acids

The controls showed high phenylalanine levels (51.3 to $60.3 \mathrm{mg} \mathrm{g}^{-1}$ protein), whereas their concentration of

Emir. J. Food Agric • Vol 32 • Issue 10 • 2020 tyrosine was low ( $<22 \mathrm{mg} \mathrm{g}^{-1}$ protein). In contrast, the FSLM01, FSLM05, FSLM22, FSLM27, FSLM28, and 
FSLM32 populations from Santa Lucia Miahuatlan had high levels of both amino acids (> 50 and $>30 \mathrm{mg} \mathrm{g}^{-1}$ protein, respectively) (Table 5). This reveals the potential of the Santa Lucia Miahuatlan populations relative to those cultivated in Coatecas Altas.

Regarding the sulfur-containing amino acids methionine and cysteine, only three Santa Lucia Miahuatlan populations (FSLM12, FSLM30, and FSLM32) showed values greater than 10 and $7.2 \mathrm{mg} \mathrm{g}^{-1}$ protein, respectively. The controls showed methionine and cysteine values lower than 8.5 and $3.2 \mathrm{mg} \mathrm{g}^{-1}$ protein, respectively. With respect to the basic amino acids, 14 populations cultivated in Santa Lucia Miahuatlan possessed high lysine, arginine, and histidine content. In contrast, the controls showed high content only of lysine and histidine, while more than $90 \%$ of the Coatecas Altas populations showed histidine levels $>15 \mathrm{mg} \mathrm{g}^{-1}$ protein (Table 5). This indicates that the region or municipality of origin influences the composition of basic amino acids. Regarding acidic amino acids, the controls as well as more than $60 \%$ of the Santa Lucia Miahuatlan populations showed aspartic and glutamic acid levels higher than $100 \mathrm{mg} \mathrm{g}^{-1}$ protein. In turn, only populations FCA03 and FCA14 from Coatecas Altas fulfilled this condition (Table 5). These findings show that direct use of several Santa Lucia Miahuatlan populations (FSLM01, FSLM17, FSLM22, FSLM27, FSLM30, and FSLM32) is desirable to improve nutrition because of their high content of essential amino acids.

\section{DISCUSSION}

Dry matter protein content was significantly lower

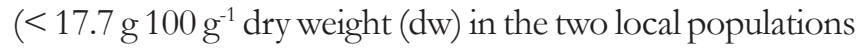

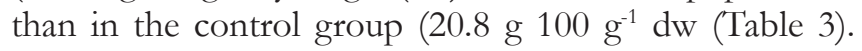
However, it was concluded that two of the Coatecas Altas populations and four of the Santa Lucia Miahuatlan populations showed no statistically significant differences from the Black Horse, Michigan, and Peruvian controls, with

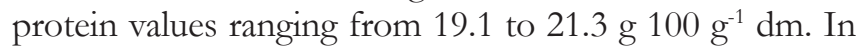
general, protein content ranged from 12.2 to $21.3{\mathrm{~g} 100 \mathrm{~g}^{-1}}^{-1}$ $\mathrm{dw}$ (Table 4). These values are within the ranges estimated by Espino-Sevilla et al. (2017) for commercial varieties in

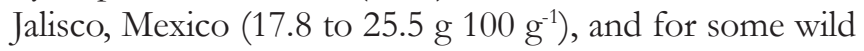
populations reported by Sotelo et al. (1995) and GuzmánMaldonado et al. (2000) (16 to $33 \mathrm{~g} 100 \mathrm{~g}^{-1}$ ). The results show that the evaluated populations have high variability with respect to the protein content of the grain.

Baptista et al. (2017) reported that 18 amino acids are present in common beans. However, this study identified only 16; the differences were tryptophan and proline. Some of the difficulties in tryptophan quantification are its low concentration in beans and the fact that acid hydrolysis destroys it (Guzmán-Maldonado et al., 2000). Nonetheless, the quantification of amino acids performed in this study allowed us to differentiate the characteristics of beans between and within two municipalities of origin, Santa Lucia Miahuatlan and Coatecas Altas, and to compare their amino acid content with that of commercial control varieties. The results show that each farmer selects varieties according to the market and culinary preferences and that the selection influences the protein and amino acid content of the harvested beans. Worthington et al. (2012) and Soleri et al. (2013) showed that each farmer in an individual community cultivates genetically different bean species and varieties. A similar phenomenon must be occurring in the municipalities of origin of the bean populations evaluated in the current study.

The evaluated amino acids were grouped into aliphatic, hydroxylated, aromatic, sulfur-containing, basic, and acidic amino acids. Within each group, essential amino acids, which help define the quality of the protein, are distinguished. Aliphatic amino acids, due to their aliphatic hydrocarbon chain structure, are not very reactive. Valine, leucine, and isoleucine are considered essential among this group. In this work, eight Santa Lucia Miahuatlan populations showed high levels of all aliphatic amino acids. In contrast, high glycine, alanine, valine, leucine, and isoleucine content was not observed in the control varieties or in the Coatecas Alta populations. Only population FCA03 of this origin presented high levels of aliphatic essential amino acids. The results show high heterogeneity in the aliphatic amino acid content of the grain that helps differentiate populations (Table 4). For essential aliphatic amino acids, Sotelo et al. (1995) reported values of 32.1 to $49.6,65.4$ to 95.4 , and 27.3 to $41.4 \mathrm{mg} \mathrm{g}^{-1}$ protein for isoleucine, leucine and valine, respectively. In turn, Guzmán-Maldonado et al. (2000) reported contents of isoleucine, leucine, and valine ranging from 31.4 to 45.3 , 48.3 to 82.1 , and 46.5 to $58.9 \mathrm{mg} \mathrm{g}^{-1}$ protein, respectively. Thus, the values reported in the literature are consistently within the ranges reported in the present work.

The hydroxylated amino acids serine and threonine are characterized by their hydrophilicity and instability under alkaline conditions. However, they participate in the formation of glycoproteins by serine glycosylation. As in the case of the aliphatic amino acids, the Santa Lucia Miahuatlan populations presented great heterogeneity. Nine populations presented high levels of both hydroxylated amino acids, in contrast to the nine Coatecas Altas populations, which showed low serine and threonine values. This reveals a contrasting pattern that suggests that the environment and cultivation practices are probably an important component that explains the different response. The controls featured 
Table 5: Content of aromatic, sulfur-containing, basic and acidic amino acids among native common bean populations cultivated in Coatecas Altas (CA) and Santa Lucia Miahuatlan (SLM), Oaxaca, Mexico.

\begin{tabular}{|c|c|c|c|c|c|c|c|c|c|}
\hline \multirow[t]{2}{*}{ Populations ID } & \multicolumn{2}{|c|}{ Aromátic $^{1}$} & \multicolumn{2}{|c|}{ Sulfured $^{1}$} & \multicolumn{3}{|c|}{ Basics $^{1}$} & \multicolumn{2}{|c|}{ Acids $^{1}$} \\
\hline & $\mathrm{Phe}^{2}$ & Tyr & Met $^{2}$ & Cys & Lys $^{2}$ & Arg & His $^{2}$ & Glu & Asp \\
\hline FSLM01 & 56.4 & 40.2 & 8.1 & 7.3 & 105.6 & 79.4 & 17.0 & 134.4 & 120.4 \\
\hline FSLM02 & 24.1 & 19.4 & 3.5 & 2.5 & 45.4 & 47.4 & 7.6 & 56.1 & 42.6 \\
\hline FSLM03 & 19.7 & 18.2 & 3.4 & 2.4 & 45.6 & 36.5 & 6.2 & 46.7 & 33.7 \\
\hline FSLM04 & 40.2 & 26.0 & 4.4 & 5.6 & 83.7 & 60.6 & 10.9 & 108.6 & 78.8 \\
\hline FSLM05 & 50.6 & 31.3 & 6.6 & 2.8 & 90.5 & 69.8 & 16.6 & 130.9 & 104.6 \\
\hline FSLM06 & 44.7 & 32.4 & 6.6 & 5.3 & 91.8 & 77.4 & 5.9 & 151.9 & 106.6 \\
\hline FSLM07 & 28.1 & 31.9 & 5.3 & 6.4 & 57.3 & 39.6 & 4.9 & 95.9 & 71.2 \\
\hline FSLM08 & 31.4 & 30.5 & 3.8 & 4.9 & 56.0 & 44.0 & 5.7 & 98.8 & 70.4 \\
\hline FSLM09 & 24.6 & 27.2 & 5.3 & 6.4 & 50.7 & 42.5 & 3.4 & 91.3 & 64.7 \\
\hline FSLM10 & 35.9 & 34.4 & 5.9 & 7.3 & 73.9 & 44.9 & 7.7 & 123.1 & 93.4 \\
\hline FSLM11 & 42.9 & 44.0 & 4.1 & 8.0 & 86.9 & 74.0 & 8.7 & 146.1 & 115.3 \\
\hline FSLM12 & 42.0 & 39.2 & 13.8 & 8.4 & 81.5 & 78.0 & 6.0 & 163.4 & 112.0 \\
\hline FSLM13 & 22.6 & 21.1 & 6.4 & 5.6 & 51.3 & 41.0 & 3.5 & 92.0 & 69.1 \\
\hline FSLM14 & 35.3 & 33.9 & 10.3 & 6.1 & 63.3 & 59.9 & 3.6 & 140.8 & 99.3 \\
\hline FSLM15 & 46.3 & 23.2 & 8.8 & 3.6 & 118.8 & 66.6 & 21.3 & 156.7 & 126.3 \\
\hline FSLM16 & 45.3 & 23.5 & 10.4 & 4.2 & 127.8 & 81.3 & 24.8 & 169.4 & 141.7 \\
\hline FSLM17 & 50.4 & 26.5 & 17.7 & 3.7 & 152.7 & 91.3 & 30.8 & 202.1 & 167.1 \\
\hline FSLM18 & 31.2 & 15.8 & 16.4 & 3.3 & 100.1 & 62.1 & 20.8 & 132.5 & 109.4 \\
\hline FSLM19 & 43.6 & 26.5 & 17.0 & 4.1 & 143.1 & 90.8 & 28.4 & 179.7 & 153.3 \\
\hline FSLM20 & 42.4 & 20.8 & 6.2 & 3.9 & 141.0 & 94.5 & 24.1 & 191.1 & 161.3 \\
\hline FSLM21 & 41.1 & 22.0 & 6.3 & 4.5 & 132.6 & 74.0 & 26.9 & 178.2 & 148.5 \\
\hline FSLM22 & 55.0 & 33.3 & 12.4 & 5.9 & 184.0 & 95.2 & 40.2 & 246.2 & 197.2 \\
\hline FSLM23 & 42.6 & 26.5 & 9.5 & 5.1 & 148.6 & 81.0 & 34.1 & 197.3 & 148.5 \\
\hline FSLM24 & 33.3 & 18.7 & 5.3 & 3.8 & 114.6 & 61.4 & 17.0 & 125.4 & 109.2 \\
\hline FSLM26 & 27.6 & 10.7 & 5.2 & 2.2 & 73.4 & 43.0 & 9.2 & 80.6 & 71.2 \\
\hline FSLM27 & 77.8 & 31.5 & 10.4 & 6.2 & 150.3 & 96.0 & 30.7 & 197.2 & 161.1 \\
\hline FSLM28 & 72.3 & 31.3 & 8.6 & 6.3 & 152.5 & 88.1 & 28.7 & 180.8 & 153.1 \\
\hline FSLM29 & 74.6 & 26.9 & 8.1 & 6.2 & 152.9 & 88.5 & 29.9 & 178.8 & 154.4 \\
\hline FSLM30 & 77.2 & 33.0 & 11.6 & 7.3 & 181.8 & 93.0 & 35.8 & 219.2 & 174.0 \\
\hline FSLM31 & 66.0 & 23.9 & 6.6 & 7.7 & 146.6 & 74.9 & 24.0 & 185.3 & 155.3 \\
\hline FSLM32 & 71.4 & 31.8 & 10.1 & 8.3 & 176.6 & 97.9 & 29.2 & 234.2 & 185.9 \\
\hline FCA01 & 15.9 & 10.5 & 4.0 & 3.5 & 19.3 & 39.9 & 5.8 & 43.4 & 27.4 \\
\hline FCA02 & 22.0 & 12.0 & 4.2 & 4.4 & 25.7 & 43.5 & 6.2 & 66.6 & 41.6 \\
\hline FCA03 & 53.6 & 29.5 & 6.2 & 3.6 & 46.0 & 82.9 & 15.1 & 136.9 & 101.4 \\
\hline FCA04 & 33.0 & 20.1 & 4.1 & 2.7 & 31.5 & 52.0 & 19.8 & 66.6 & 55.4 \\
\hline FCA05 & 35.5 & 24.0 & 5.5 & 5.3 & 38.7 & 49.9 & 16.3 & 81.9 & 58.6 \\
\hline FCA06 & 24.9 & 18.4 & 5.0 & 2.7 & 29.1 & 50.1 & 15.6 & 52.8 & 33.0 \\
\hline FCA07 & 39.4 & 18.3 & 4.3 & 3.5 & 48.1 & 47.7 & 26.8 & 57.1 & 52.8 \\
\hline FCA08 & 51.7 & 25.6 & 6.6 & 3.8 & 50.3 & 71.9 & 19.5 & 126.9 & 91.7 \\
\hline FCA09 & 47.0 & 28.4 & 5.2 & 3.0 & 64.9 & 79.9 & 28.4 & 100.1 & 71.1 \\
\hline FCA10 & 29.5 & 21.1 & 5.1 & 3.1 & 43.5 & 48.4 & 20.9 & 62.4 & 41.6 \\
\hline FCA12 & 23.9 & 21.0 & 4.0 & 2.8 & 29.3 & 50.6 & 21.0 & 49.6 & 31.5 \\
\hline FCA13 & 27.7 & 19.4 & 4.2 & 2.4 & 36.0 & 52.3 & 18.6 & 66.7 & 43.2 \\
\hline FCA14 & 53.9 & 27.2 & 5.2 & 4.2 & 67.1 & 74.1 & 22.5 & 133.2 & 100.2 \\
\hline FCA15 & 19.4 & 14.9 & 4.3 & 3.4 & 34.6 & 42.1 & 20.3 & 53.3 & 35.3 \\
\hline FCA16 & 29.4 & 18.5 & 4.4 & 5.7 & 61.4 & 54.7 & 20.5 & 61.5 & 32.5 \\
\hline Black H. & 51.3 & 20.5 & 5.5 & 3.0 & 103.5 & 59.4 & 21.8 & 133.2 & 103.8 \\
\hline Michigan & 55.6 & 21.6 & 8.3 & 3.1 & 110.0 & 66.2 & 22.6 & 141.5 & 114.6 \\
\hline Peruano & 60.3 & 21.8 & 4.3 & 2.5 & 117.6 & 67.6 & 22.7 & 159.0 & 119.1 \\
\hline DHS-Tukey ${ }^{3}$ & 14.6 & 8.4 & 3.9 & 2.7 & 27.4 & 20.9 & 8.3 & 50.3 & 37.9 \\
\hline
\end{tabular}

${ }^{1}$ Content of amino acids in $\mathrm{mg} \mathrm{g}^{-1}$ protein; ${ }^{2}$ Content of essential amino acids; $3 \mathrm{DHS}=$ Honest significant difference as determined by Tukey's test; differences equal to or greater than Tukey's value indicates significant differences 
high threonine (31.6 to $34.8 \mathrm{mg} \mathrm{g}^{-1}$ protein) and low serine content (49.1 to $56.4 \mathrm{mg} \mathrm{g}^{-1}$ protein). This contrasts with the best Santa Lucia Miahuatlan populations, in which threonine and serine were present at 51.5 to 85.8 and 112.0 to $207.4 \mathrm{mg} \mathrm{g}^{-1}$ protein, respectively (Table 4). This reveals the high potential for direct use of beans obtained from the cultivars from Santa Lucia Miahuatlan. The population evaluated from Santa Lucia Miahuatlan presented higher serine content than the populations analyzed by Sotelo et al. (1995) and Rezende et al. (2017), which contained 41.3 to 69.3 and 70.0 to $74.0 \mathrm{mg} \mathrm{g}^{-1}$ protein, respectively. However, the threonine values reported by the same authors were similar to those reported in the literature, ranging from 31.3 to 58.9 and 55.0 to $61 \mathrm{mg} \mathrm{g}^{-1}$ protein, respectively.

The evaluated aromatic amino acids, phenylalanine and tyrosine, are characterized by their stability and serve as precursors of biological and bioactive compounds. The controls presented values of 51.3 to $60.3 \mathrm{mg}$ phenylalanine $\mathrm{g}^{-1}$ protein and 20.5 to $21.8 \mathrm{mg}$ tyrosine $\mathrm{g}^{-1}$ protein. These quantities are lower than the best estimates for the Santa Lucia Miahuatlan population, which are 66.0 to 77.8 and 30.5 to $40.2 \mathrm{mg} \mathrm{g}^{-1}$ protein, respectively. The Coatecas Altas populations showed low values (Table 5). The total aromatic amino acid (phenylalanine + tyrosine) content of beans from native populations ranged from 37.9 to $110.2 \mathrm{mg} \mathrm{g}^{-1}$ protein. These values are within the ranges reported by Sotelo et al. (1995), Guzmán-Maldonado et al. (2000), and Rezende et al. (2017), who reported 65.5 to 93.6, 47.0 to 118.0 , and 97.0 to $105.0 \mathrm{mg}$ of aromatic amino acids $g^{-1}$ protein, respectively.

Sulfur amino acids (methionine and cysteine) are essential but are unstable to oxidation. Cysteine is involved in the stabilization of tertiary and quaternary protein structure through the formation of disulfide bridges. Between municipalities of origin, a differential variation was observed; for example, in Santa Lucia Miahuatlan, methionine ranged from 3.4 to $17.7 \mathrm{mg} \mathrm{g}^{-1}$ protein and cysteine ranged from 2.2 to $8.4 \mathrm{mg} \mathrm{g}^{-1}$ protein. In contrast, the original Coatecas Altas populations showed values of 4.0 to $6.6 \mathrm{mg}$ and 2.4 to $5.7 \mathrm{mg}$ of methionine and cysteine $\mathrm{g}^{-1}$ protein, respectively. Thus, the content of sulfur amino acids (methionine + cysteine) ranged from 19.7 to $22.4 \mathrm{mg} \mathrm{g}^{-1}$ protein (Table 5). These results are within the variation reported by Sotelo et al. (1995) and GuzmánMaldonado et al. (2000), who reported 4.4 and $23.9 \mathrm{mg} \mathrm{g}^{-1}$ protein, respectively, values superior to the values of 12.8 and $16.7 \mathrm{mg} \mathrm{g}^{-1}$ protein reported by Schumacher et al. (2011) for beans and peas, respectively.

Basic amino acids (lysine, arginine, and histidine) are hydrophilic in nature and may present polarity depending on the $\mathrm{pH}$ of the surrounding medium. In addition, lysine is especially unstable. A group of 17 Santa Lucia Miahuatlan populations featured the highest lysine (100.1 to $181.8 \mathrm{mg} \mathrm{g}^{-1}$ protein), arginine (71.9 to $97.9 \mathrm{mg} \mathrm{g}^{-1}$ protein), and histidine (17.0 to $40.2 \mathrm{mg} \mathrm{g}^{-1}$ protein) content; this can be compared to the populations from Coatecas Altas (61.4 to $64.9,71.9$ to 79.9 , and 18.6 to $28.4 \mathrm{mg} \mathrm{g}^{-1}$ protein, respectively) (Table 5). The results show significantly different population patterns that are due to different environmental conditions and different cultivation and management regimes. Some Santa Lucia Miahuatlan populations featured lysine and arginine values higher than those reported by Sotelo et al. (1995) for common bean (48.0 to 74.2 and 47 to $70.5 \mathrm{mg}$ lysine and arginine $\mathrm{g}^{-1}$ protein, respectively) but similar to those reported by Rezende et al. (2017) (93 and $104 \mathrm{mg}$ of lysine and arginine $g^{-1}$ protein). This indicates that both the genotype and the agroecological conditions under which the cultivar is raised influence the content of basic amino acids.

Glutamic and aspartic acid have carboxyl groups and form peptide bonds; they are hydrophilic and are responsible for protein loads. Four Santa Lucia Miahuatlan populations contained more than $200 \mathrm{mg}$ of glutamic acid and more than $167 \mathrm{mg}$ of aspartic acid $\mathrm{g}^{-1}$ protein, superior to the controls and to the Coatecas Altas populations. The latter had values lower than those of the controls (Table 5). In fact, more than $60 \%$ of the original Santa Lucia Miahuatlan populations showed high content of both amino acids, indicating a potential contribution of the cultivar's agroecological conditions. These values are higher than those reported by Rezende et al. (2017) (167 to 189 and 135 to $147 \mathrm{mg}$ glutamic and aspartic acid $\mathrm{g}^{-1}$ protein, respectively) and are within the range reported by Sotelo et al. (1995) (55 to 279 and 118 to $236 \mathrm{mg}$ glutamic and aspartic acid $g^{-1}$ protein, respectively).

The populations with the highest content of the evaluated essential amino acids (valine, leucine, isoleucine, threonine, phenylalanine, methionine, lysine, and histidine) were FSLM01, FSLM22, FSLM27, FSLM28, FSLM30, and FSLM32, all from Santa Lucia Miahuatlan; these populations outscored the Black Horse, Michigan, and Peruvian controls (Tables 4 and 5). In other words, the protein quality of six Santa Lucia Miahuatlan populations is higher than that of commercial varieties. This highlights their nutritional value, considering that higher levels of essential amino acids correspond to greater protein bioavailability (Gropper and Smith, 2013). Regarding environmental influence, Wang et al. (2017) and Barampana and Simard (1993) determined that temperature and precipitation influence the protein and amino acid content of the common bean. In terms of management, soils with high $\mathrm{K}, \mathrm{Mg}$, and organic matter content also favor the highest protein-grain concentration (Florez et al., 2009). 


\section{CONCLUSIONS}

The results show that the beans consumed by the farmers' families in individual communities have different protein and amino acid content and that these features are highly variable among bean samples. This variation is explained by the genetic characteristics of the cultivated varieties and by agroecological-environmental influences and cultivation regime. However, the protein content of the grain is as high as $19.9 \%$ and shows an adequate balance of aliphatic, hydroxylated, aromatic, sulfur-containing, basic, and acidic amino acids. This protein contribution has high nutritional value and is available at low cost to families in rural communities.

\section{ACKNOWLEDGEMENTS}

The authors are grateful for the financial support provide by Consejo Nacional de Ciencia y Tecnología CONACYTProblemas Nacionales (Project no. 2015-1119) and Instituto Politécnico Nacional (Projects nos. 20196672 and 20201270). ARFS received a scholarship from the CONACyT (No. 447652) to study a Master's in Food Sciences.

\section{AUTHORS' CONTRIBUTIONS}

ENAB, ACM and JLCS conceived, designed, and performed the experiments, ARFS, JLCS, ENAB, AMVG, JCCR and JEAJ wrote, compiled and conducted the laboratory and statistical analysis. All authors read and approved the final manuscript.

\section{REFERENCES}

Alaiz, M., J. L. Navarro, J. Girón and E. Vioque. 1992. Amino acid analysis by high-performance liquid chromatography after derivatization with diethyl ethoxymethylenemalonate. J. Chromatogr. A. 591: 181-186.

Alsmeyer, R. H., A. E. Cunningham, and M. L. Happich. 1974. Equations predict PER from amino acid analysis. Food Technol. 28: $34-40$.

Audu, S. S. and M. O. Aremu. 2011. Nutritional composition of raw and processed pinto bean (Phaseolus vulgaris L.) grown in Nigeria. J. Food Agric. 9: 72-80.

Baptista, A., O. Pinho, E. Pinto, S. Casal, C. Mota and I. M. Ferreira. 2017. Characterization of protein and fat composition of seeds from common beans (Phaseolus vulgaris L.), cowpea (Vigna unguiculata $L$. Walp) and bambara groundnuts (Vigna subterranea L. Verdc) from Mozambique. Food Measure. 11: 442-450.

Barampama, Z. and R. E. Simard. 1993. Nutrient composition, protein quality and antinutritional factors of some varieties of dry beans (Phaseolus vulgaris) grown in Burundi. Food Chem. 47: 159-167.

Bitochi, E., L. Nanni, E. Bellucci, M. Rossi, A. Giardini, P. S. Zeuli and R. Papa. 2012. Mesoamerican origin of the common bean (Phaseolus vulgaris L.) is revealed by sequence data. Proc. Natl. Acad. Sci. U. S. A. 109: E788-E796.

Black, R. E., C. G. Victora, S. P. Walker, Z. A. Bhutta, P. Christian, M. De Onis, M. Ezzati, S. Grantham-McGregor, J. Katz, R. Martorell and R. Uauy. 2013. Maternal and child undernutrition and overweight in low-income and middle-income countries. Lancet. 382: 427-451.

Boye, J., R. Wijesinha-Bettoni and B. Burlingame. 2012. Protein quality evaluation twenty years after the introduction of the protein digestibility corrected amino acid score method. Brit. J. Nutr.108: S183-S211.

Bradford, M. M. 1976. A rapid and sensitive method for the quantitation of microgram quantities of protein utilizing the principle of protein-dye binding. Anal Biochem. 72: 248-254.

Carbas, B., N. Machado, D. Oppolzer. L. Ferreira, M. Queiroz, C. Brites, E. A. Rosa and A. I. Barros. 2020. Nutrients, antinutrients, phenolic composition, and antioxidant activity of common bean cultivars and their potential for food applications. Antioxidants. 9: 186.

Chávez-Mendoza, C. and E. Sánchez. 2017. Bioactive compounds from Mexican varieties of the common bean (Phaseolus vulgaris): Implications for health. Molecules. 22: 1360.

Chávez-Servia, J. L., E. Heredia-García, N. Mayek-Pérez, E. N. Aquino-Bolaños, S. Hernández-Delgado, J. C. CarrilloRodríguez, H. R. Gill-Langarica and A. M. Vera-Guzmán. 2016. Diversity of common bean (Phaseolus vulgaris L.) landraces and the nutritional value of their grains. In: A. K. Goyal (Ed.), Grain Legumes. InTech, Rijeka, Croatia, pp. 1-33.

Espino-Sevilla, M. T., L. R. Pérez-Bernala, M. Z. Reyna-Villelaa, D. Rojas-Bravoa and E. C. Lugo-Cervantesa. 2017. Composición y caracterización de las proteínas de las principales variedades de frijol (Phaseolus vulgaris $L$.) que se cultivan en el estado de Jalisco, México. Investig. Des. Cien. Tecnol. Aliment. 2: 72-76.

FAOSTAT. 2013. Food Supply Crops Primary Equivalent. Available from: http://www.fao.org/faostat/en/\#data/CC/visualize. [Last accessed on 2020 Apr 21].

Florez, A., M. Pujolà, J. Valero, E. Centelles, A. Almirall and F. Casañas. 2009. Genetic and environmental effects on chemical composition related to sensory traits in common beans (Phaseolus vulgaris L.). Food Chem. 113: 950-956.

Freudenberg, A., K. J. Petzke and S. Klaus. 2012. Comparison of high-protein diets and leucine supplementation in the prevention of metabolic syndrome and related disorders in mice. J. Nutr. Biochem. 23: 1524-1530.

Grimble, R. F. 2006. The effects of sulfur amino acids intake on immune function in humans. J. Nutr. 136: 1660S-1665S.

Gropper, S. S. and J. L. Smith. 2013. Advanced Nutrition and Human Metabolism. $6^{\text {th }}$ ed. Cengage Learning, Belmont, CA, USA, Wadsworth.

Gundogan, R. and A. C. Karaca. 2020. Physicochemical and functional properties of proteins isolated from local beans of Turkey. LWT Food Sci. Technol. 130: 109609.

Guzmán-Maldonado, S. H., J. Acosta-Gallegos and O. Paredes-López. 2000. Protein and mineral content of a novel collection of wild and weedy common bean (Phaseolus vulgaris L.). J. Sci. Food Agric. 80: 1874-1881.

Henderson, J. W., R. D. Ricker, B. A. Bidlingmeyer and C. Woodward. 2000. Rapid, Accurate, Sensitive, and Reproducible HPLC Analysis of Amino Acids. Application Bulletin 5980-1193E. Agilent Technologies, Palo Alto, California, USA, p. 10.

Kigel, J. 1999. Culinary and nutritional quality of Phaseolus vulgaris 
seeds as affected by environmental factors. Biotechnol. Agron. Soc. Environ. 3: 205-209.

Li, P, Y. L. Yin, D. F. Li, S. W. Kim and G. Wu. 2007. Amino acids and immune function. British J. Nutr. 98: 237-252.

Marliss, E. B., S. Chevalier and R. Gougeon. 2006. Elevations of plasma methylarginines in obesity and ageing are related to insulin sensitivity and rates of protein turnover. Diabetologia 49: 351-359.

Pérez, P., G. Esquivel, R. Rosales and J. A. Acosta-Gallegos. 2002. Caracterización física, culinaria y nutricional de frijol del altiplano subhúmedo de México. Arch. Latinoam. Nutr. 52: 172-180.

Rezende, A. A., M. T. B. Pacheco, V. S. N. da Silva and T. A. P. de Casto-Ferreira. 2017. Nutritional and protein quality of dry Brazilian beans (Phaseolus vulgaris L.). Food Sci. Technol. 38: 421-427.

Schumacher, H., H. M. Paulsen, A. E. Gau, W. Link, H. U. Jürgens, O. Sass and R. Dieterich. 2011. Seed protein amino acid composition of important local grain legumes Lupinus angustifolius L., Lupinus luteus L., Pisum sativum L. and Vicia faba L. Plant Breed. 130: 156-164.

Soleri, D., M. Worthington, F. Aragón-Cuevas, S. E. Smith, and P. Gepts. 2013. Farmers' varietal identification in a reference sample of local Phaseolus species in the Sierra Juárez, Oaxaca, Mexico. Econ. Bot. 67: 283-298.

Sotelo, A., H. Sousa and M. Sanchez. 1995. Comparative study of the chemical composition of wild and cultivated beans (Phaseolus vulgaris). Plant Foods Hum. Nutr. 47: 93-100.

Wang, N., A. Hou, J. Santos and L. Maximiuk. 2017. Effects of cultivar, growing location, and year on physicochemical and cooking characteristics of dry beans (Phaseolus vulgaris). Cereal Chem. 94: 128-134.

Worthington, M., D. Soleri, F. Aragón-Cuevas and P. Gepts. 2012. Genetic composition and spatial distribution of farmer-managed Phaseolus bean plantings: An example from a village in Oaxaca, Mexico. Crop Sci. 52: 1721-1735. 